\title{
Plantation species-specific adjustment functions for the Forest Carbon Predictor in New Zealand
}

Peter N. Beets ${ }^{*}$ D, Mark O. Kimberley, Graeme R. Oliver, Stephen H. Pearce, J. Doug Graham, David Henley and

Dean F. Meason

\begin{abstract}
Background: New Zealand's planted forest area is dominated by radiata pine (90\%), but also includes Douglas-fir $(6 \%)$, and a range of minor species including eucalypts and cypress. Carbon sequestration in planted forest is currently estimated using yield tables from the Forest Carbon Predictor (FCP), which was designed to estimate dry matter in live biomass and dead organic matter pools in radiata pine stands. Stand variables required as model inputs include basal area, mean top height, stocking, and tending regime. In addition, wood density needs to be measured or estimated. When the FCP is applied to plantation species other than radiata pine, dry matter estimates may need to be adjusted to remove bias.
\end{abstract}

Methods: To test for and remove bias, existing biomass studies were compiled and additional biomass data collected to fill gaps. Measured dry matter stock estimates were compared with predictions from the FCP model. Species assessed included Pseudotsuga menziesii (10 stands), Cupressus lusitanica (2), Eucalyptus regnans (7), E. nitens (5), E. saligna (7), E. botryoides (2), E. fastigata (2), and Acacia dealbata (2).

Results: Stem bark and crown components were higher in Douglas-fir than predicted by the FCP, whereas crown components were appreciably lower in hardwood species than predicted. Root biomass estimates in Douglas-fir and hardwood species were similar to predictions from the FCP. Dead organic matter stock estimates were similar in Douglas-fir to predictions from the FCP. Dry matter predictions from the model were adjusted by species or species group, to help reduce model prediction error when the FCP is applied to these species. Model bias for Douglasfir averaged $4.1 \%$ for aboveground live biomass, with a root mean square error of $12.9 \%$. Model bias for hardwood species averaged $-0.11 \%$ for aboveground live biomass, with a root mean square error of $16.1 \%$. Owing to data limitations, model bias was poorly estimated for dead organic matter pools.

Conclusions: This study has shown that forest carbon models that have been developed for well-studied plantation species can be adapted with some degree of certainty and applied to other species with suitable, albeit limited, biomass data in order to improve the accuracy of predictions of stand biomass and carbon sequestration.

Keywords: Biomass, Organic matter stocks, Douglas-fir, Eucalyptus, Cypress, Radiata pine, Forest carbon model

\footnotetext{
*Correspondence: peter.beets@scionresearch.com
}

Scion, Private Bag 3020, Rotorua 3046, New Zealand 


\section{Introduction}

Unbiased estimates of carbon stocks and changes in New Zealand's planted and natural forests are required to meet international reporting commitments under the United Nations Framework Convention on Climate Change and the Kyoto Protocol (IPCC 2003). Pinus radiata D.Don (radiata pine) comprises approximately 90\% of NZ's exotic plantation forest area of 1.7 million ha, Pseudotsuga menziesii (Mirb.) Franco (Douglas-fir) comprises approximately $6 \%$, while the remaining $4 \%$ is comprised of less common hardwood and softwood species (Ministry for Primary Industries 2016). Less common commercial species include Cupressus lusitanica Mill. (cypress), Eucalyptus regnans F. Muell., E. nitens (Deane et Maid.) Maid, E. saligna Sm., E. botryoides Sm., E. fastigata Deane et Maid., and Acacia dealbata Link. Cupressus macrocarpa Hartw. was widely planted in New Zealand from the 1860s but is susceptible to canker (Van der Werff 1988) and the timber is particularly difficult to dry without distortion (Haslett 1986). Because of these issues, interest has focused on C. lusitanica.

Carbon stocks in planted forest in New Zealand are estimated using yield tables derived from a modelling system called the Forest Carbon Predictor (FCP). The FCP is a stand-level model that uses summary data from field plots, the silvicultural regime applied to that stand, and soil fertility and climate data to predict wood density and dry matter stocks per ha, as described in Beets et al. (2011). When applied to radiata pine, the FCP links stem gross and net annual volume increment predictions from the 300 Index growth model (Kimberley et al. 2005) with estimates of growth sheath wood density (Beets et al. 2007a), which are used in C_Change to predict the dry matter content in live and dead organic matter pools annually over a rotation (Beets et al. 1999; Garrett et al. 2010; Garrett et al. 2012). The growth partitioning model, C_Change, predicts the dry matter content of needles, branches, stem wood, stem bark, roots, and reproductive parts based on expansion factors derived from biomass time series studies undertaken in radiata pine stands in New Zealand. The model includes mortality functions for estimating dry matter inputs to dead organic matter pools resulting from natural mortality and mortality related to pruning and thinning activities, and decay functions for estimating losses from dead organic matter pools owing to decay (Beets et al. 1999). The FCP applies carbon fractions to dry matter predictions to calculate carbon (Beets and Garrett 2018). The accuracy of carbon stock predictions from the FCP has been assessed using independent biomass, coarse woody debris, and fine litter data from radiata pine stands sampled across a range of stand ages and silvicultural regimes (Beets et al. 2011).

The FCP is also used to estimate carbon stocks for less common commercial species; however, the accuracy of these predictions has not been determined. The FCP model uses basal area, mean top height, stocking, timing and intensity of pruning and thinning operations, and wood density of trees at each biomass plot as model inputs, which ensures that predictions from the model are strongly constrained by the field plot data. A previous model validation study by Beets et al. (2011) showed that predictions from the FCP were unbiased when applied to radiata pine. However, when the FCP was applied to other commercial tree species in New Zealand, preliminary comparisons of measured and modelled dry matter stock estimates indicated large differences among species. This was expected as there are large species differences in wood density and growth partitioning which are reflected by, for example, stem wood to bark ratios and crown to stem ratios. Differences between measured and modelled estimates were also evident in dead wood and litter pools, which would be expected to occur if there are species differences in, for example, needle retention and dead tree component decay rates. Predictions from the FCP model, therefore, need to be adjusted, to match measured stock estimates.

In this study, the FCP was applied to commercial species other than radiata pine, to test for bias and to develop adjustment factors to remove model prediction error. The magnitude of the model estimation bias resulting from species differences in, for example, wood density, stem form, growth partitioning to biomass components, and component decay rates will depend on the particular combination of submodels used when the FCP is applied to a particular species. The adjustments presented in this paper were derived using existing biomass data compiled for this paper and new biomass data acquired to address gaps, and were applied on a species- and component-specific basis in the FCP.

When applied to Douglas-fir, the FCP uses the 500 Index growth model (Knowles 2005) and a wood density model (Beets et al. 2018), which were both developed specifically for Douglas-fir, to predict stem wood dry matter production from stem volume and wood density. However, the dry matter content of other live (stem bark, needles, branches, roots) and dead (woody debris and litter) organic matter components were predicted using C_Change, which has only been parameterised for radiata pine (Beets et al. 1999). When applied to cypress, the FCP uses the radiata pine 300 Index growth model, the radiata pine wood density model, and C_Change, while for hardwood (e.g. eucalypt) species the FCP uses the 300 Index growth model, the mean breast height outer wood basic density for the species (Cown et al. 1991), and C_Change.

The objective of this paper was to tabulate data from existing and new biomass studies in Douglas-fir, $C$. 
lusitanica, and E. regnans, E. nitens, E. saligna, $E$. botryoides, E. fastigata, and $A$. dealbata stands in New Zealand and derive adjustment functions for the FCP to improve prediction of carbon sequestration. The adjustment functions aim to correct for species difference in crown-stem relationships, wood to bark ratios, root to shoot ratios, and decay rates of dead tree component. If acceptable, adjustments are possible using a relatively small number of biomass studies for the species assessed; this would obviate the need to re-parameterise the FCP for each species, while still providing reasonably accurate predictions of carbon sequestration on an existing modelling platform.

\section{Methods}

The derivation of adjustment functions was based on FCP version 5.1. Inputs used in the FCP include stand basal area, mean top height, stocking, silvicultural management regime (initial stocking, pruning and thinning ages and intensities), and site factors (mean annual air temperature, soil fertility, needle retention). These data were obtained from temporary sample plots installed at each biomass study site and were used as model inputs to predict dry matter stocks in live and dead organic matter pools annually over a rotation, following methods given in Beets et al. (2011). Predictions from the FCP were compared with the sample-based measurements of tree biomass, dead wood, and forest floor mass from each site.

\section{Sample plots}

Fixed area plots (c. 0.04 ha) were installed in the stand selected for biomass determination. Plots were mostly rectangular, but where planting rows were indistinct, circular plots were used. Field measurements included stem diameter at breast height (DBH at 1.4 $\mathrm{m}$ aboveground level) of all standing trees, and total and pruned heights of sample trees selected across the diameter range. Counts were made of missing and cut-stumps in planting rows, which, together with stand records, were used to determine the initial stocking, and the timing and intensity of thinning and pruning operations.

\section{Aboveground biomass}

Sample tree biomass determination procedures are outlined below. Typically, eight trees per stand, selected across the DBH range, were felled and their biomass determined. This entailed measuring total height and diameter over bark at the base $(0.1 \mathrm{~m})$, $0.7 \mathrm{~m}$ and $1.4 \mathrm{~m}(\mathrm{DBH})$, and at $2-\mathrm{m}$ intervals along the entire stem length for calculation of stem volume over-bark. The oven-dry mass of the crown was determined as follows: the stem was divided into height zones, which varied from 1 to $3 \mathrm{~m}$ in length, depending on total tree length. All dead branches below the live crown were removed, placed on a tarpaulin and weighed fresh in the field. Two of these dead branches were randomly selected and weighed fresh in the field, dried at $70^{\circ} \mathrm{C}$ to constant weight (the drying temperature used in New Zealand biomass studies), and dry weight recorded. For each height zone within the live crown, all branches were removed from the stem, partitioned into live and dead branch categories, and each category weighed fresh in the field, and then two representative live branches and one dead branch from each zone were randomly selected, weighed fresh in the field, and oven-dry weight determined separately for dead and live branch matter, foliage, and reproductive parts. If cone shedding was evident (e.g. in Douglas-fir), the biomass of reproductive parts was considered to be unmeasured. The dry weight of the tree crown components in each zone was calculated by multiplying the sample branch component dry weights by the crown fresh weight sampling fraction. Total crown dry weight was obtained by summing all zone component weights. Stem oven-dry mass was determined as follows: A 5-cm-thick disc sample was cut at the base of each $2-\mathrm{m}$ stem section (except at $0.10 \mathrm{~m}$ where a 2.5-cm-thick disc was taken). The over- and under-bark diameters of each disc were measured to provide wood and bark volume, and samples dried to constant weight. The total dry weight of each stem was calculated by multiplying the stem disc dry weights by the stem volume sampling fraction. Aboveground live (AGL) biomass was obtained by summing the crown and stem components.

\section{Belowground biomass}

Following felling, an excavator was used to initially loosen the soil around each stump, followed by lifting the entire root system. Lateral roots from adjacent trees were easily recognisable and excluded. During excavation, broken-off sections of roots were dug up by hand (to allow assembly of missing root sets, as described below). Intact root systems and broken sections of roots were transported to the laboratory and washed to remove most soil. All broken roots $\geq 5 \mathrm{~mm}$ in diameter were counted. In addition, small/broken roots between 2 and $4 \mathrm{~mm}$ in diameter were assessed on one or two large roots (usually one tap or sinker root and one lateral root).

Sets of sample root were assembled to represent missing roots, by matching the observed diameter, taper, and structure of attached complete roots. These were washed on a sieve, and oven-dried at $70{ }^{\circ} \mathrm{C}$, and weighed. Regression equations relating root oven-dry 
mass to root basal diameter were applied to the empirical data to determine the oven-dry mass of missing roots. Individual roots from intact root systems were cut and separated from the root stock and divided into the following diameter size classes; $<1 \mathrm{~cm}$, $1-5 \mathrm{~cm}, 5-10 \mathrm{~cm},>10 \mathrm{~cm}$ and root stock (belowground bole), washed free of soil on a sieve, and oven-dried to constant weight before weighing. Root size classes were summed to give the total belowground biomass. The aboveground stump section was oven-dried and included as part of the stem.

Aboveground live (AGL) and belowground live (BGL) dry matter (DM) content ( $t / h a)$ of forest plots was calculated from sample tree component weights using the plot basal area ratio method (Madgwick 1981).

\section{Dead wood}

Coarse woody debris (CWD) volume (dead wood $>10$ $\mathrm{cm}$ diameter), primarily from thinning operations, was assessed by measuring the large- and small-end diameter (to a small-end diameter of $10 \mathrm{~cm}$ ) and length of each piece within the biomass plot boundary. A 5-cm-thick disc was cut from the centre of each CWD piece after measuring the CWD diameter at that point. The stem bark was intact and the heartwood was sound. However, the sapwood was decayed and could be fragmented by hand, and care was therefore required to prevent compression of the debris when measuring diameters and to avoid loss of material when sampling discs. Discs were bulked to provide one sample for oven-dry weight determination and density calculation. The dry matter ( $t / h a)$ content of CWD was calculated by multiplying the total CWD volume/ha by the mean density of sample discs. At sites where the CWD volume was not measurable because it was highly decayed, it was sampled as part of the forest floor material.

\section{Forest floor}

Forest floor material in the biomass plots was estimated using a $0.25-\mathrm{m}^{2}$ sampling frame. Material collected included fresh litter (L: layer-shed cones, and foliage and branch litter $<10 \mathrm{~cm}$ diameter) and older material (FH: Fermenting and Humus) material, down to the surface of the mineral soil. Five samples (one per quadrant and one near the plot centre) were collected per plot, individually bagged and transported to the laboratory where live roots (sometimes present in $\mathrm{FH}$ ) were removed prior to oven drying to constant weight. Forest floor sampling procedures invariably include some mineral soil and therefore the dry matter ( $t / h a)$ content of the forest floor was calculated from the ash-corrected sample dry weights (to exclude mineral soil) and horizontal area of the sampling frames.

\section{Soil fertility and temperature}

Either 20 or 30 mineral soil cores $(0-5 \mathrm{~cm}$ deep) were collected systematically from within each plot using a 25-mm diameter Hoffer tube sampler. These core samples were bulked to give one soil sample per plot for determination of carbon $(\mathrm{C})$ and nitrogen $(\mathrm{N})$ with a Leco CNS-2000 furnace (LECO Corp., St Joseph, MI, USA). The soil $\mathrm{C}$ and $\mathrm{N}$ data and mean annual air temperature (MAT) for each site were required model inputs to predict the wood density of annual growth sheaths (Beets et al. 2007a; Beets et al. 2018). Mean annual air temperatures for each site were obtained from climate data collected by the National Institute of Water and Atmospheric Research (NIWA).

\section{Development of species-specific adjustment functions}

The FCP model inputs differed among species, site-related stand data available, and parameters associated with each sub-model, as elaborated for each species or species group below:

\section{Douglas-fir stand data}

Biomass study sites and summary data for each stand are provided in Appendix 1. New studies include a 10-year-old stand in Southland, a 9- and a 19-year-old stand in Canterbury, a 21-year-old stand in Southern Kaingaroa, a 28-year-old stand in Northern Kaingaroa, and a 31-year-old stand in Whakarewarewa forest near Rotorua. Stand attributes were measured in temporary sample plots installed at each site. Measurements were taken of stocking rate, basal area, mean top height, dry weight of biomass components (foliage, branches, stem wood, stem bark), stem volume (over- and under-bark), the mass of dead wood and litter, as well as outerwood basic density at breast height (1.4 $\mathrm{m}$ aboveground). The number of annually produced needle-age classes retained in the lower third of the green crown of a sample tree was counted and the mean needle retention of sample trees calculated for each plot. Most cones had been shed, and these were weighed as part of the forest floor. Attached cones, if present, were weighed with the branches. Root biomass was measured at one site in northern Kaingaroa. The forest floor (LFH, ash free) was measured at most sites, although negligible litter was present in young stands. The mass was assumed to be zero in such cases. For example, at the 10-year-old stand at Gowan Hill and the 9-year-old stand at Forest Creek, Douglas-fir litter was mostly absent, which was to be expected because needle retention was reasonably high in these stands $(4-5$ years of retained material). Deadwood at the Northern Kaingaroa (thinned to 800 trees $\mathrm{ha}^{-1}$ at age 16) and Whakarewarewa (thinned to 750 trees $\mathrm{ha}^{-1}$ at age 18) 
sites was measured 12 and 13 years, respectively following thinning. Although the sapwood and stem bark were present, some hollowing and collapse of sapwood was evident. However, the heartwood was sound.

Existing Douglas-fir above and belowground live tree biomass and litter data from Nordmeyer and Ledgard (1993) and Nordmeyer (unpublished data) were compiled for analysis. The aboveground biomass sampling procedures used historically were similar to those used in the new studies. However, the belowground biomass sampling procedure that involved large pit excavation differed substantially from the current procedure (whole root-system excavation). The historical studies were conducted in 15- and 28-year-old stands at Trig E, Craigieburn Range (1040 m elevation) measured in 1980 and remeasured in 1993, a 13-year-old stand at Bridge Hill, Craigieburn Range ( $900 \mathrm{~m}$ located below the Trig E stand) measured in 1993, and a 10-year-old stand at Ribbonwood, Upper Waitaki $(500 \mathrm{~m})$ measured in 1997. The two stands at Trig E were thinned from 4000 tree $\mathrm{ha}^{-1}$ to 2700 trees $\mathrm{ha}^{-1}$ and pruned to $2-\mathrm{m}$ height at stand age 13 (Nordmeyer and Ledgard 1993); however, the dead wood and branch residues arising from these operations were not measured. Forest floor litter was measured in these stands, but these data were not always usable due to the lack of litterfall (for example the 10 -year-old stand at Ribbonwood contained litter derived predominantly from understorey grasses) (Nordmeyer pers. comm.). For these sites, the Douglas-fir litter estimate was assumed to be zero. The Bridge Hill and Ribbonwood stands were unthinned when the biomass studies were undertaken, and woody debris was absent. At Trig E, whole stem wood density of the 15 -year-old stand was reported to be $442 \mathrm{~kg} \mathrm{~m}^{-3}$, and the site mean annual temperature was $8.0^{\circ} \mathrm{C}$ (Nordmeyer and Ledgard 1993).

\section{Model inputs for Douglas-fir}

Tree stocking, basal area, mean top height, needle retention, soil C/(N-0.014) ratio (Beets et al. 2018), site mean annual air temperature, and silvicultural history data for the sites were entered into the Forest Carbon Predictor (500 Index model, Douglas-fir wood density model (Beets et al. 2018), and C_Change), which provide dry matter estimates for tree biomass components (needles, branches, stem wood, stem bark, cones, roots) and dead organic matter (CWD and LFH). As needle retention exceed 3 years, the maximum needle retention parameter for radiata pine of 3 years was used within the model.

\section{Hardwood stand data}

Biomass study sites and summary data for each stand are provided in Appendix 2. New biomass studies included an 8-year-old Eucalyptus fastigata stand at Kapenga in the Central North Island and a 26-year-old E. regnans stand within Kinleith forest. Stand attributes measured at each site were stocking rate, basal area, mean top height, dry weight of biomass components (foliage, branches, stem wood, stem bark), stem volume (both under and over bark), the mass of dead wood and litter, as well as outerwood basic density at breast height (1.4 $\mathrm{m}$ aboveground). Root biomass of five of the eight biomass sample trees in the 8-year- old E. fastigata stand was measured. The E. fastigata stand was unthinned, and woody debris was, therefore, absent at that site. Litter (LFH, ash free) was measured at both sites.

Existing biomass data from 23 studies undertaken in New Zealand hardwood stands were located (Frederick et al. 1985a, 1985b, 1985c, 1986, Madgwick et al. 1981). These biomass data were generally limited to the determination of aboveground tree dry matter by component and stem volume (under- and over-bark). Species included Eucalyptus regnans (6 stands), E. nitens (5), E. fastigata (1), E. saligna (7), E. botryoides (2) and Acacia dealbata (2). Stand age ranged between 3 and 17 years, and stocking ranged between 350 and 7250 trees $\mathrm{ha}^{-1}$.

\section{Model inputs for hardwoods}

Tree stocking, basal area, mean top height, and silvicultural history data for each plot were entered into the Forest Carbon Predictor, which provided dry matter estimates for tree biomass components (leaves, branches, stems, roots) and dead organic matter (CWD and litter (LFH). Leaf retention was not measured so the maximum for radiata pine (3 years) was used for hardwoods because they were all evergreen species. Breast height outerwood density was not measured in historical studies so it was estimated from tree age using wood density functions for exotic tree species growing in New Zealand (Appendix 3). Breast height outerwood density was converted to growth sheath density using the model for radiata pine (Beets et al. 2007a).

\section{Cupressus lusitanica data}

Biomass study sites and summary data for each stand are provided in Appendix 4. New biomass studies in $C$. lusitanica included a 20-year-old stand at an ex-pasture site at Manawahe, and a 29-year-old stand near Rotorua. Stand attributes measured at each site included stocking, basal area, mean top height, dry weight of biomass components, stem volume (inside and over bark), the mass of dead wood and litter, and breast height (1.4 m aboveground) outerwood basic density. Root biomass was not measured at either site. 


\section{Model inputs for C. lusitanica}

Tree stocking, basal area, mean top height, and silvicultural history data for each plot (from forest management records and determinations in the field) were entered into the FCP (using the 300 Index Growth model, radiata pine wood density model, and C_Change), which provided dry matter estimates for tree biomass components (leaves, branches, stems, roots) and dead organic matter (CWD and litter (LFH). Leaf retention is not possible to determine in cypress so the maximum for radiata pine (3 years) was used. Wood density was estimated from the soil $\mathrm{C} /(\mathrm{N}-0.014)$ ratio and site mean annual temperature using the model for radiata pine (Beets et al. 2007a).

\section{Development of adjustment functions}

Linear relationships were fitted through the origin between the sample-based estimates of tree biomass, dead wood, and forest floor dry matter and the unadjusted predictions from the FCP. The slope coefficients from these relationships were then applied to predictions from the FCP (adjusted predictions) on a species- and component-specific basis. To test for bias, adjusted predictions from the FCP were subtracted from the measured dry matter stocks and the average of the residuals expressed as a percentage of the measured mean dry matter stock. The root mean square error was calculated as the square root of (variance of the residuals minus the square of the bias) and was expressed as a percentage of the measured mean dry matter stock.

\section{Results}

Adjustment functions for Douglas-fir

The oven dry mass of aboveground tree components, dead wood, and litter of Douglas-fir stands at 10 biomass sites (from Appendix 1) and corresponding predictions obtained using the FCP prior to adjustment functions being applied are shown in Fig. 1. The $y=$ $x$ line indicates that Douglas-fir stands have more dry matter in stem bark, crown components, dead wood, and forest floor components compared to FCP estimates for radiata pine at the corresponding stand age, mean top height, basal area, and stocking (Fig. 1).

The slope coefficient for stem wood (1.03) is close to 1.0 because stem wood is predicted using stem

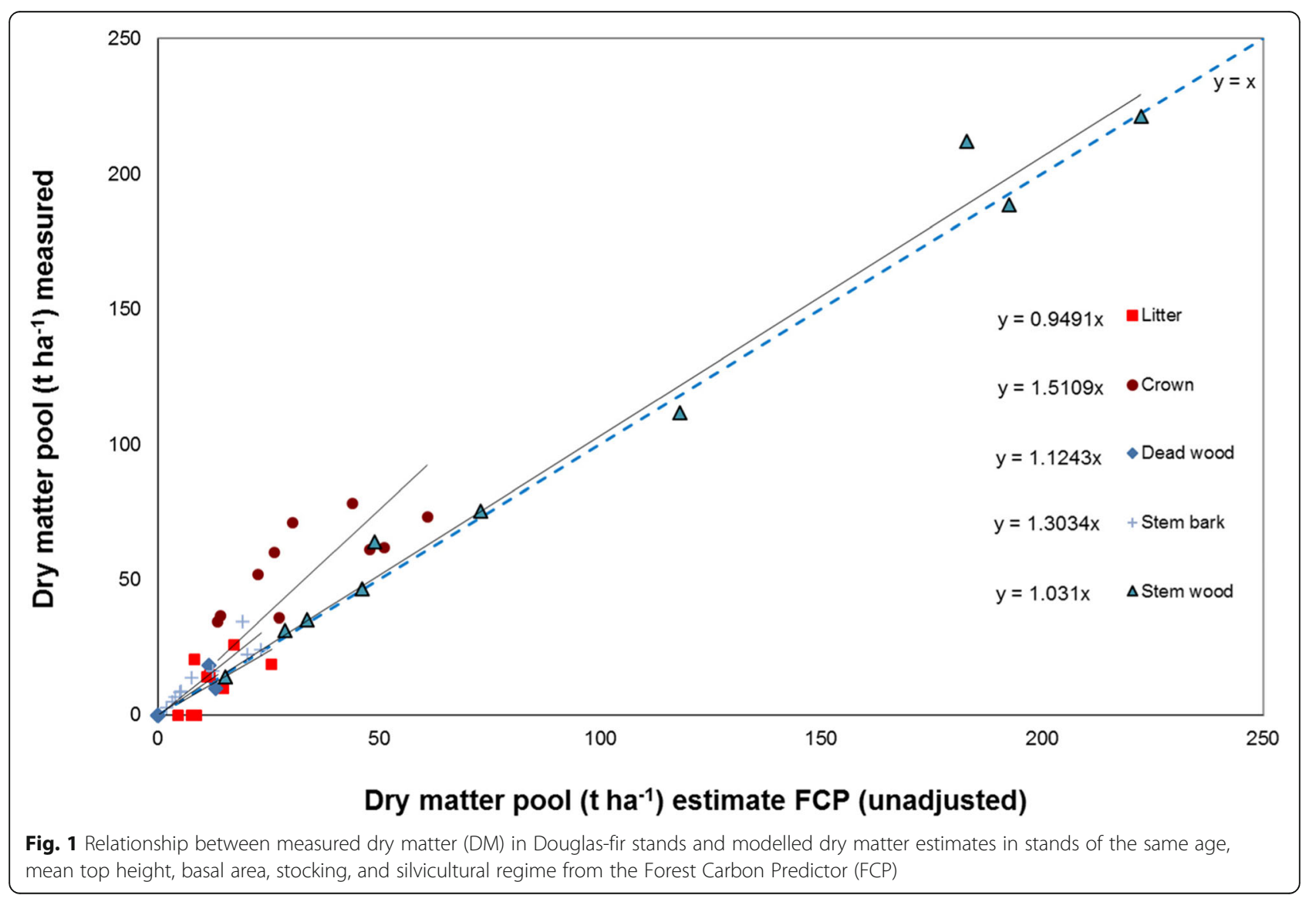


volume and wood density models developed specifically for Douglas-fir. The slope coefficients for stem bark (1.30) and crown (1.51) indicate that Douglas-fir stands have more stem bark relative to stem wood, and appreciably more needle and branch dry matter relative to radiata pine (Fig. 1). The high crown mass in Douglas-fir is primarily a reflection of the high needle retention (which attains around 8 years or more at some sites) and also the architecture of Douglas-fir which has more branches per unit of stem length than radiata pine. The coefficients for litter (0.95) and dead wood (1.12) indicate that Douglas-fir stands have slightly less dry matter in litter and a comparable amount of dead wood compared to radiata pine.

The Douglas-fir (PMEN) adjustment functions for the FCP are:

Stemwood PMEN $=1.031 \times(\text { stemwood })_{\text {PMEN }}$

Stembark $_{\text {PMEN }}=1.3034 \times$ stembark $_{\text {PRAD }}$

Crown $_{\text {PMEN }}=1.5109 \times($ needles + live branch + dead

branch) $)_{\text {PRAD }}$

Deadwood $_{\text {PMEN }}=1.1243 \times$ Deadwood $_{\text {PRAD }}$

Litter $_{\text {PMEN }}=0.9491 \times$ Litter $_{\text {PRAD }}$
$\mathrm{AGL}_{\text {PMEN }}=$ Stemwood $_{\text {PMEN }}+$ Stembark $_{\text {PMEN }}+$

CrOWn $_{\text {PMEN }}$

$\mathrm{BGL}_{\text {PMEN }}=\mathrm{AGL}_{\mathrm{PMEN}} \times\left(\mathrm{BGL}_{\mathrm{PRAD}} / \mathrm{AGL}_{\mathrm{PRAD}}\right)$

Total $_{\text {PMEN }}=\mathrm{AGL}_{\mathrm{PMEN}}+\mathrm{BGL}_{\mathrm{PMEN}}+$ Deadwood $_{\mathrm{PMEN}}+$ Litter $_{\text {PMEN }}$

where PRAD is radiata pine, AGL is aboveground live biomass, and BGL is belowground live biomass.

The root to shoot ratio for radiata pine (c. 20\%) (Beets et al. 2007b) was assumed to apply to Douglas-fir, in order to be consistent with the results at Northern Kaingaroa (where tree root systems were individually excavated in total) and with results from international studies where root/shoot ratios were c. 20\% (Ranger and Gelhaye 2001).

Measured aboveground tree components, dead wood and litter are compared with adjusted predictions from the FCP in Fig. 2. Young Douglas-fir stands included in this study all had high needle retention (with 6-8 years of needle age classes retained), while the two mature stands both had low retention (Northern Kaingaroa and Whakarewarewa retained only three age classes of needles), which partly explains the apparent non-linear variability evident

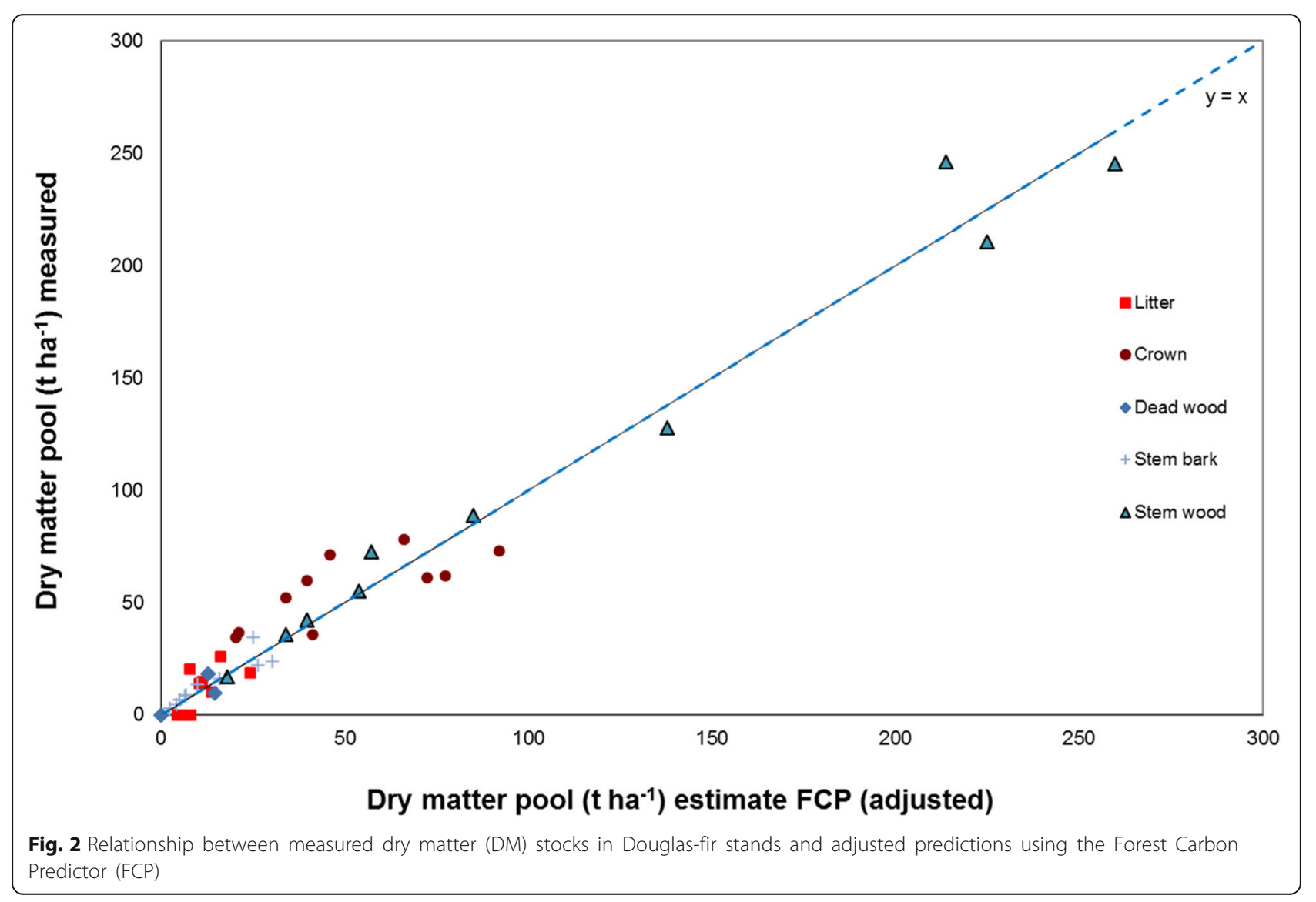


(Fig. 2), and may result in some bias when the FCP is applied to specific sites. Tree crowns contributed most bias (9.5\%), followed by stem bark (6.2\%), and stem wood $(0.8 \%)$. Model bias averaged $-0.12 \%$ for litter biomass, with a root mean square error of $66 \%$. Model bias averaged $4.1 \%$ for aboveground live biomass, with a root mean square error of $12.9 \%$. There was insufficient coarse woody debris measurement data to test for model bias. Aboveground live dry matter comprised $76 \%$ of the total live plus dead organic matter in these 10 stands, based on the FCP, so the contribution from dead organic matter was relatively small.

\section{Adjustment functions for hardwoods}

The oven dry mass of aboveground tree components at 25 biomass sites (Appendix 2) and corresponding predictions obtained using the FCP are shown in Fig. 3. The slope coefficient for crowns is considerably less than 1.0 which indicates that hardwood species have less foliage and branch dry matter than estimated using the FCP (Fig. 3a). In contrast, the slope coefficient for stems exceeds 1.0 which indicates that hardwood stands have more stem dry matter than estimated using the FCP (Fig. 3b).

The hardwood adjustment functions for the FCP are:

$$
\begin{aligned}
& \text { Stem }_{\text {Hardwood }}=1.1572 \times(\text { Stem wood }+ \text { bark })_{\text {PRAD }} \\
& \text { Crown }_{\text {Hardwood }}=0.3725 \times \text { (leaves }+ \text { live branches }+ \text { dead } \\
& \text { branches) })_{\text {PRAD }} \\
& \mathrm{AGL}_{\text {Hardwood }}=\mathrm{Stem}_{\text {Hardwood }}+\text { Crown }_{\text {Hardwood }}
\end{aligned}
$$

As in Douglas-fir, belowground live biomass carbon (BGL $\mathrm{BHardwood}_{\text {H }}$ ) in Eucalyptus and Acacia species was estimated using the modelled root/shoot ratio for radiata pine. The root:shoot ratio for hardwoods was only measured at one site ( $E$. fastigata at Kapenga). The dry matter stock belowground was $20.4 \mathrm{t} / \mathrm{ha}$, and aboveground live dry matter was $126.8 \mathrm{t} / \mathrm{ha}$, giving a root/shoot ratio of 0.16 , which was similar to ratios reported for Eucalyptus plantations in Australia (Snowden et al. 2000). The FCP estimate of root dry matter at Kapenga was $29.4 \mathrm{t}$ $\mathrm{ha}^{-1}$, which may be a slight overestimate for eucalyptus, although root biomass data are too limited to be certain.

Dead wood and litter pools were not directly measured in hardwood biomass studies, so stock adjustments were assumed to mirror aboveground components, using the following functions:

Dead wood $_{\text {Hardwood }}=1.1572 \times$ Dead wood $_{\text {PRAD }}$
Litter $_{\text {Hardwood }}=0.3725 \times$ Litter $_{\text {PRAD }}$

Total dry matter (excluding mineral soil organic matter) was estimated by summing the four pools:

$$
\begin{aligned}
& \text { Total }_{\text {Hardwood }}=\mathrm{AGL}_{\text {Hardwood }}+\mathrm{BGL}_{\text {Hardwood }}+\text { Dead } \\
& \text { wood }_{\text {Hardwood }}+\mathrm{Litter}_{\text {Hardwood }}
\end{aligned}
$$

Measured aboveground tree components are compared with adjusted predictions from the FCP in Fig. 4. The measured biomass values are aligned with the $y=x$ line. Model bias calculated across hardwood species averaged $-0.11 \%$ for aboveground live biomass, with a root mean square error of $16.1 \%$.

\section{Adjustment functions for Cupressus lusitanica}

Biomass data from two stands (Appendix 3) have been acquired to prepare adjustment functions for C. lusitanica. The oven dry mass of aboveground tree components (crown separate from stem) at biomass sites and corresponding predictions obtained using the FCP are shown in Fig. 5. The slope coefficient for stems (1.0729) exceeds 1.0, which indicates that $C$. lusitanica stands have more stem dry matter than estimated using the FCP. The slope coefficient for crowns (1.7561) is much larger than 1.0, which indicates that cypress stands have considerably more foliage and branch dry matter than estimated using the FCP (Fig. 5).

The cypress aboveground live biomass was estimated from the FCP using the following functions:

$$
\begin{aligned}
& \text { Stem }_{\text {cypress }}=1.0729 \times(\text { Stem wood }+ \text { bark })_{\text {PRAD }} \\
& \text { Crown }_{\text {cypress }}=1.7561 \times(\text { leaves }+ \text { live branches }+ \text { dead } \\
& \text { branches) })_{\text {PRAD }} \\
& \mathrm{AGL}_{\text {cypress }}=\text { Stem }_{\text {cypress }}+\text { Crown }_{\text {cypress }}
\end{aligned}
$$

The root to shoot ratio of cypress stands was not measured, and the ratio for radiata pine is assumed to apply to the cypress.

For dead wood and litter pools, stock adjustments were assumed to be similar to the aboveground components, with the following functions used:

$$
\begin{aligned}
& \text { Dead wood }_{\text {cypress }}=1.0729 \times \text { Dead wood }_{\text {PRAD }} \\
& \text { Litter }_{\text {cypress }}=1.7561 \times \text { Litter }_{\text {PRAD }}
\end{aligned}
$$

Total dry matter (excluding mineral soil organic matter) was estimated by summing the four pools:

$$
\begin{aligned}
& \text { Total } \\
& \text { cypress } \\
& + \text { Litter }_{\text {cypress }}
\end{aligned}
$$

Measured aboveground tree components are compared with adjusted predictions from the FCP in 


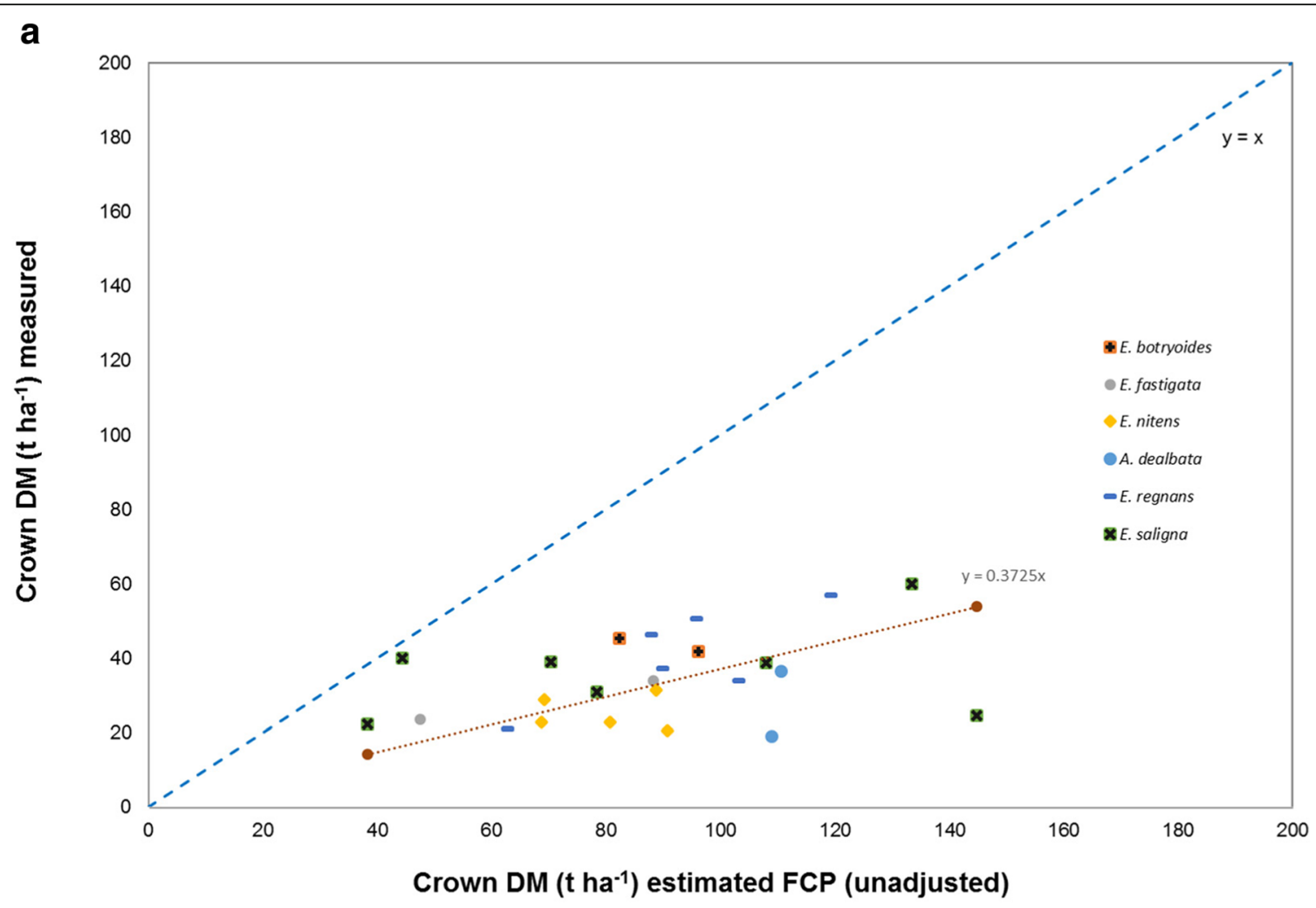

b

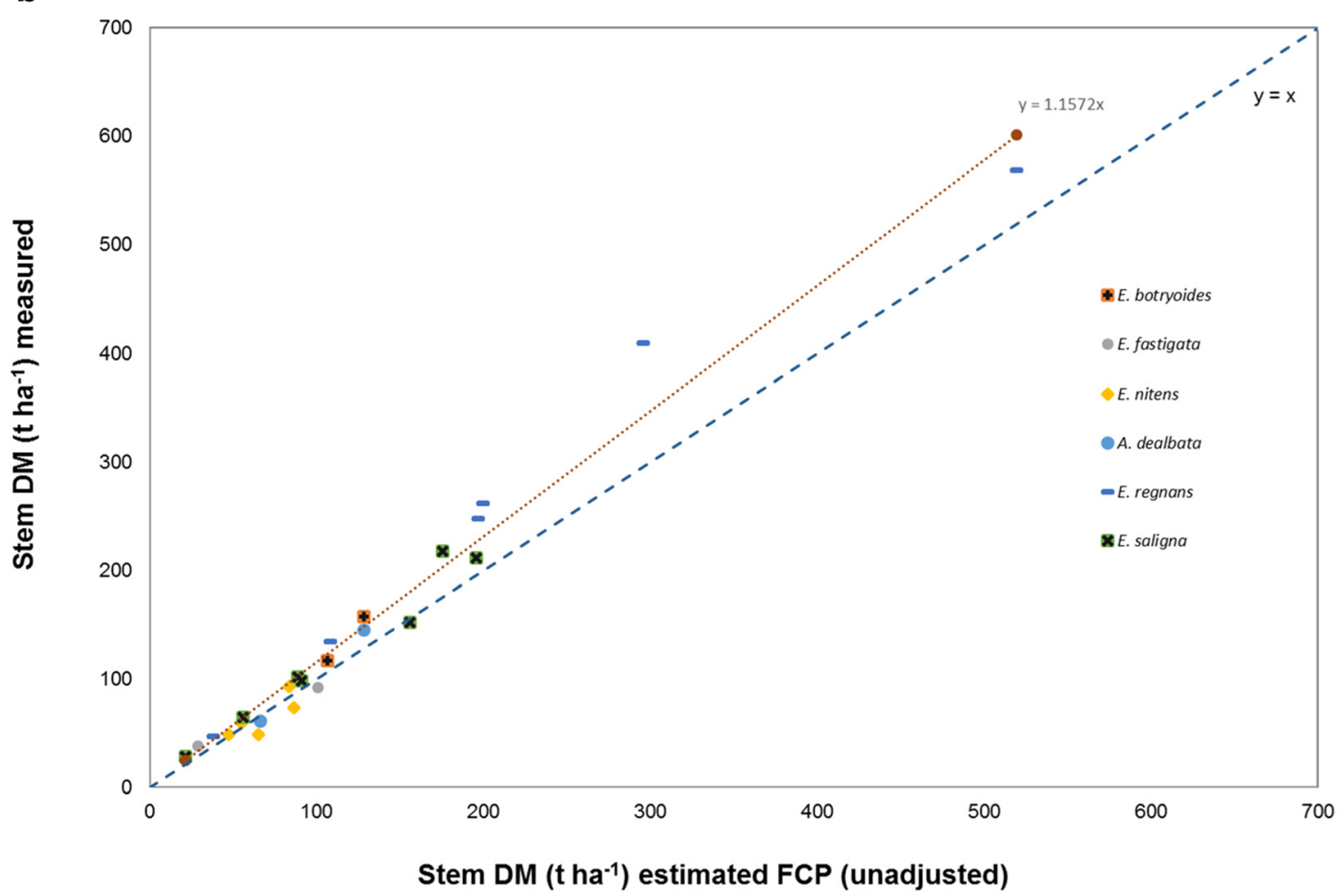

Fig. 3 Relationship between measured dry matter (DM) in Eucalyptus and Acacia species and DM in stands of the same age, mean top height, basal area, stocking, and silvicultural regime estimated using the Forest Carbon Predictor (FCP) for a crown and $\mathbf{b}$ stem components 


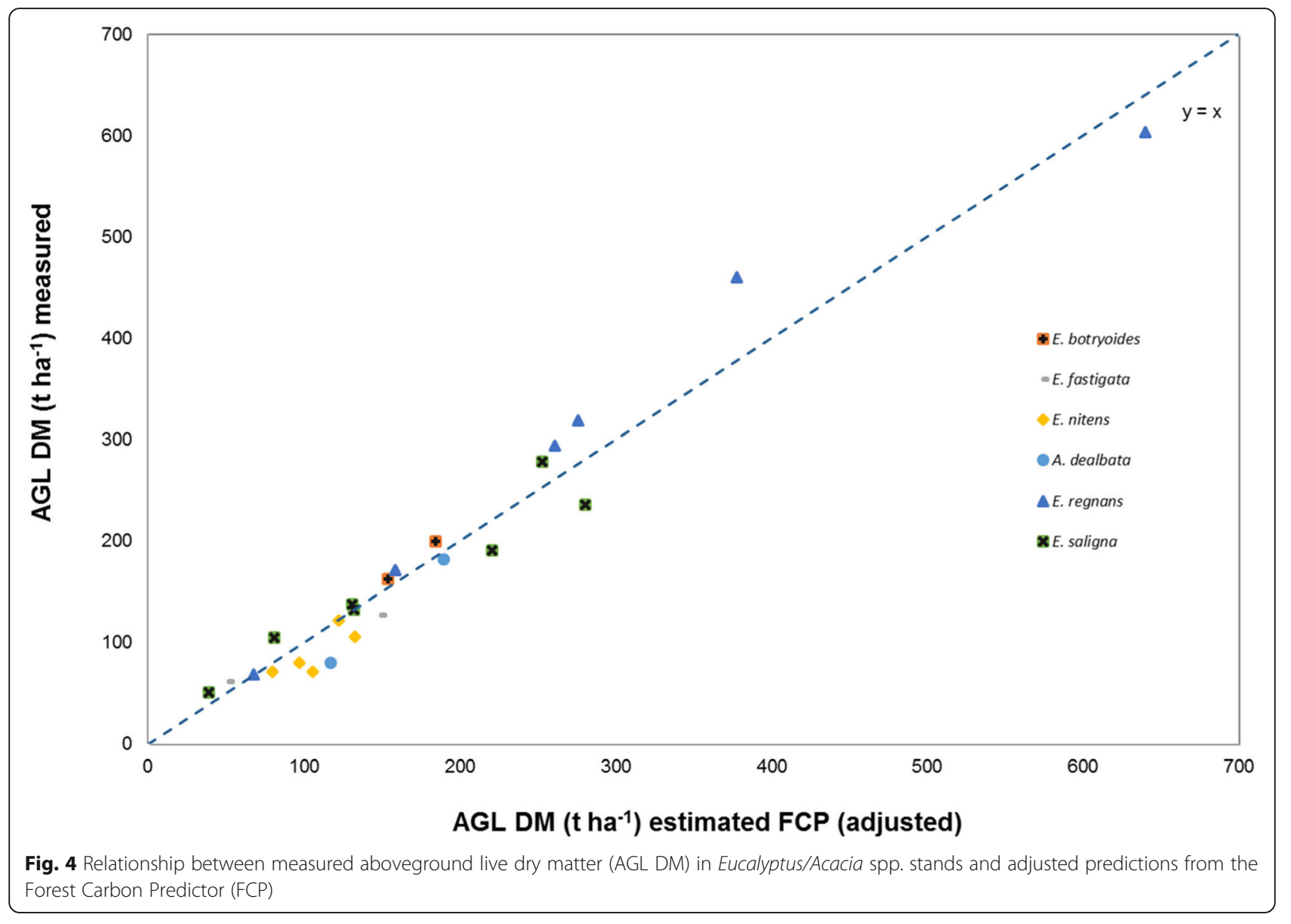

Fig. 6. The measured biomass values are aligned with the $y=x$ line. There were insufficient data to test for model bias.

\section{Discussion}

Douglas-fir crowns have more densely spaced branches and retain more needle age classes than radiata pine, and the stem has proportionally more bark than radiata pine. The adjustment functions applied to the FCP to allow for these differences performed adequately with respect to total aboveground live biomass and appeared to be reasonable for dead organic matter pools (Fig. 2). However, there was a tendency for the adjusted aboveground live biomass to be underestimated in young stands (around 10 years of age), which was ascribed to the needle retention parameter. The maximum value that can be used is 3 years in C_Change. However, needle retention can range between three and eight or more years in Douglas-fir. The young stands sampled for biomass were in cool areas of the South Island, where trees are generally healthier than elsewhere in New Zealand and the needle retention parameter greatly exceeds 3 years. If more stands had been sampled, including young stands with low needle retention in the North Island and mature stands in the South Island with high needle retention, the underestimation referred to above would probably not have been evident. The analysis undertaken here was based on the assumption that a linear relationship forced through the origin is more appropriate than a non-linear relationship when developing adjustments based on small sample sizes.

The root to shoot ratio from Nordmeyer (pers. comm.) ranged between 33 and 38\%, which is considerably higher than Douglas-fir at Northern Kaingaroa (19\%). The Douglas-fir data collected by Nordmeyer were obtained using a variable area pit method (Nordmeyer pers. comm.), which may overestimate root biomass relative to shoot biomass. For example, the 28-year-old Trig E stand with $307 \mathrm{tha}^{-1}$ of aboveground biomass had $118 \mathrm{tha}^{-1}$ of belowground biomass (Appendix 1), compared with c. 60$80 \mathrm{tha}^{-1}$ of root biomass in stands with c. $300 \mathrm{tha}^{-1}$ of aboveground biomass (Ranger and Gelhaye 2001). 


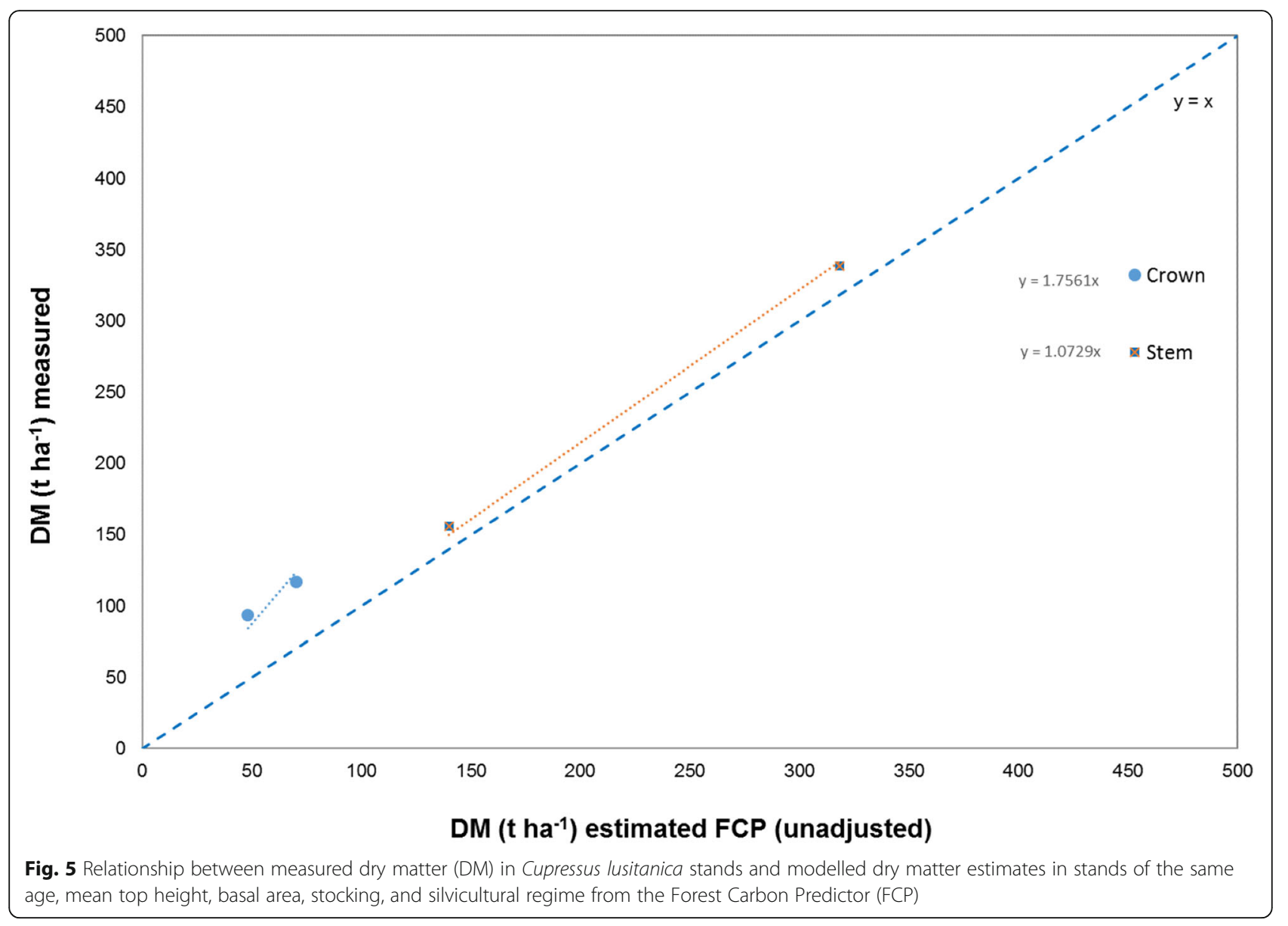

Root to shoot ratios obtained using complete root system excavation procedures for Douglas-fir growing in New Zealand and globally (Ranger and Gelhaye 2001) averaged c. 20\%, which indicates that radiata pine root to shoot ratios apply to Douglas-fir as well. Therefore, no species-specific adjustments for root predictions were applied in the FCP.

In contrast, hardwoods have less biomass within their crowns than radiata pine. In hardwoods, the measured stem volume included the volume of large limbs greater than $10 \mathrm{~cm}$ in diameter, which would in part explain why stem volume would have been underestimated by the model and, conversely, crown mass overestimated. The variability evident (Fig. 4) possibly relates to variation on branching and consequential effects on stem taper. Model bias calculated across hardwood species averaged only $0.11 \%$, which demonstrates that the adjustment functions for hardwoods performed adequately for crown and stem components. The tabulated breast height outerwood density for each species was used as an input into the model. This approach removed a major source of variation in stem dry matter among species and allowed the use of a single adjustment function across all hardwood species. Unlike Douglas-fir and C. lusitanica, previous studies with Eucalyptus spp. and Acacia dealbata show little regional variation in outer wood density in New Zealand (Appendix 4). The root to shoot ratio for radiata pine was assumed to apply to hardwood species, to be consistent with results from the limited number of belowground biomass studies undertaken in New Zealand (this study) and Australia, where root to shoot ratios of c. $20 \%$ have been reported (Snowden et al. 2000).

For $C$. lusitanica, stem dry matter was underestimated while crown dry matter was underestimated by the model. In these respects, cypress was similar to Douglas-fir. The accuracy of the adjustments for cypress is uncertain, given that the adjustment functions are based on only two stands. At least six biomass studies across a range of stand ages would provide sufficient data to develop more accurate adjustment functions for a less common species. 


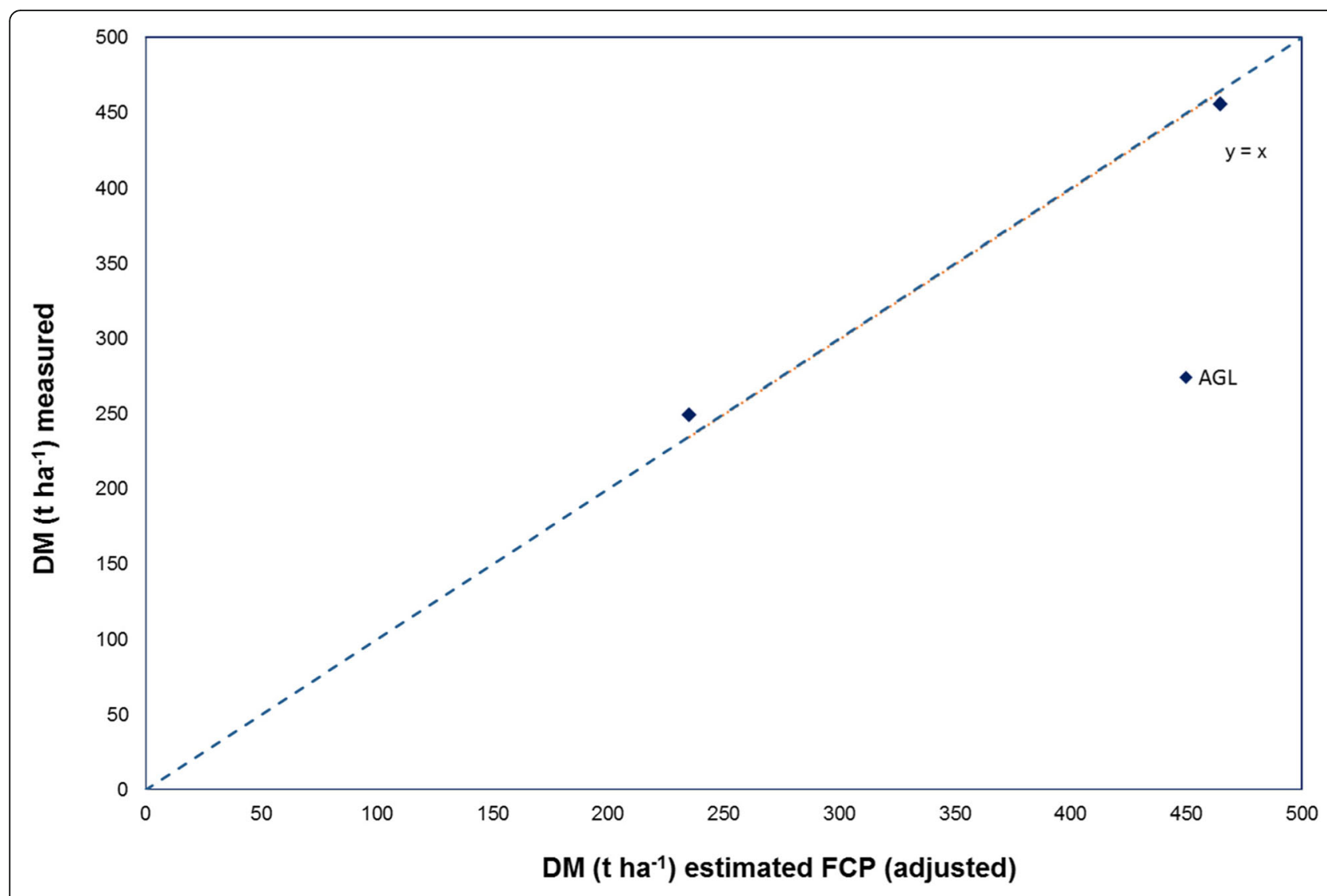

Fig. 6 Relationship between measured crown and stem dry matter (DM) in Cupressus lusitanica stands and adjusted predictions using the Forest Carbon Predictor (FCP)

Carbon yield values obtained from the FCP are useful for predicting carbon stocks at stand ages other than at the age when the plots were measured. For radiata pine (using the 300 Index growth model), it has been shown that robust carbon-stock predictions are possible when projecting growth at least 5 years on either side of the plot measurement date (Beets et al. 2011). While not tested, predictions for Douglas-fir should be similarly robust, provided that the 500 Index growth model (the growth model developed specifically for Douglas-fir) is used. However, for other species in New Zealand, robust growth models have not yet been developed, and hence the accuracy of carbon stocks predictions several years before or after the plot measurements is uncertain. Even so, carbon stock estimates at the plot measurement date are expected to be robust, as was shown clearly for hardwoods (Fig. 4), provided that the 300 Index model is specified and the appropriate adjustment functions are applied. Unbiased estimates of forest carbon are required for national and international reporting purposes which is difficult to demonstrate for species with limited data.

\section{Conclusions}

Unbiased estimates of forest carbon are required for national and international reporting purposes which is difficult to demonstrate for species with limited data.

- This study has shown that forest carbon models that have been developed for well-studied plantation species can be adapted with some degree of certainty and applied to other species with suitable, albeit limited, biomass data in order to improve the accuracy of predictions of stand biomass and carbon sequestration.

- Adjustment functions were developed and incorporated into the Forest Carbon Predictor (initially developed for radiata pine) to reduce model prediction error when applied to Douglas-fir, $C$. lusitanica, a range of Eucalyptus species, and Acacia dealbata in New Zealand.

- To provide robust carbon stock estimates, adjustment functions need to be based on 10 or more biomass studies per species or species group and include measurements of live and dead organic matter pools. 


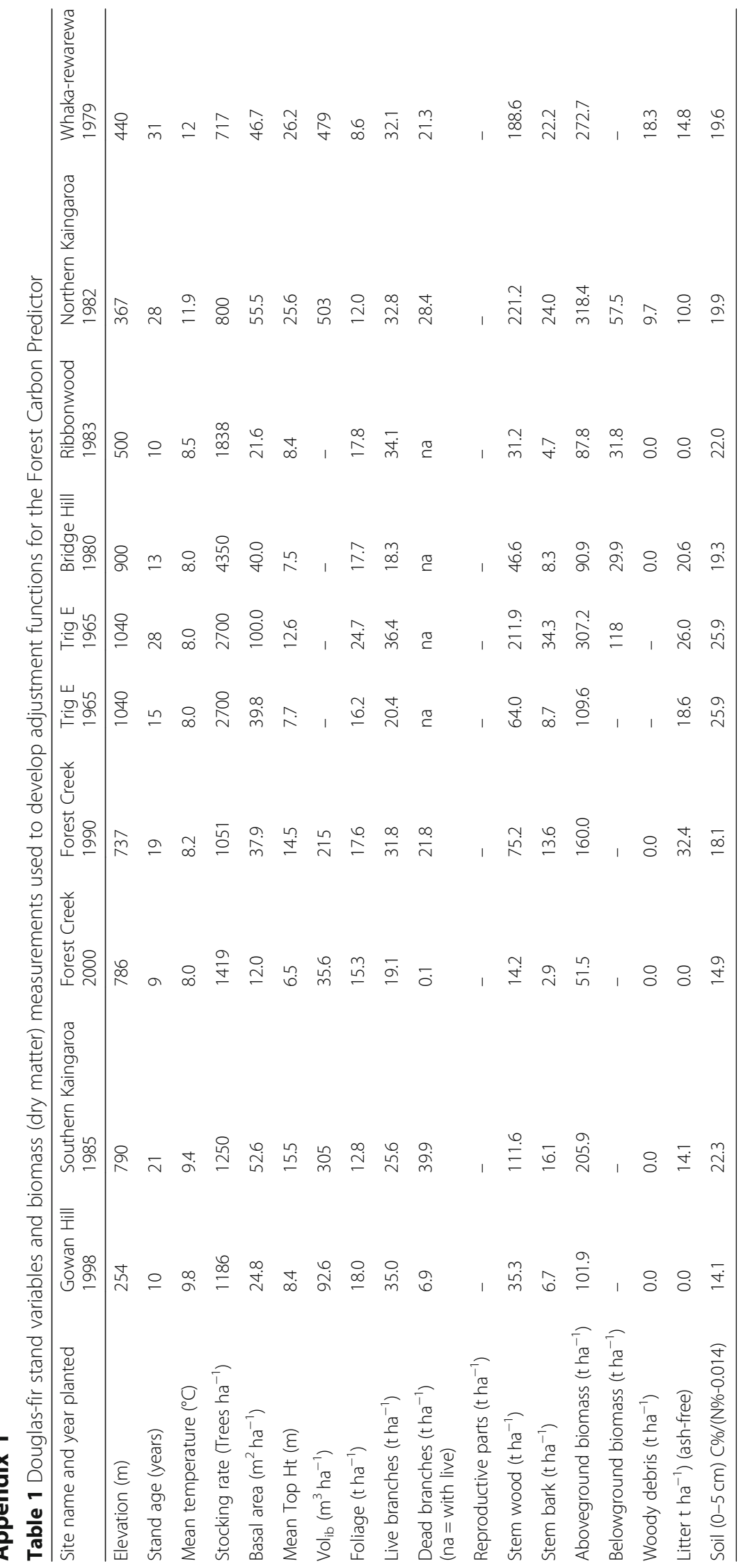




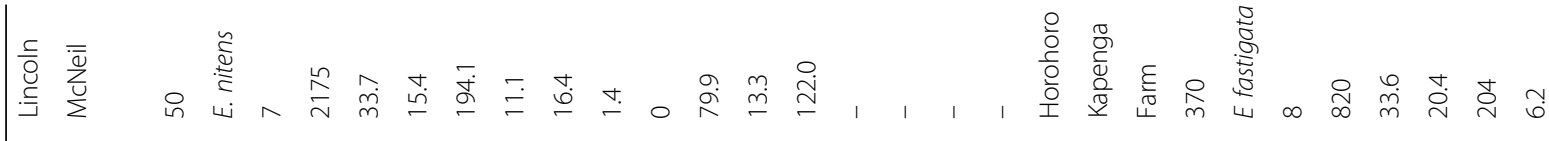

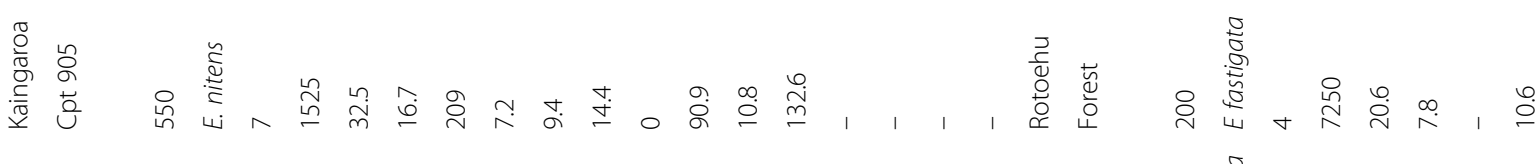

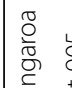
品竎

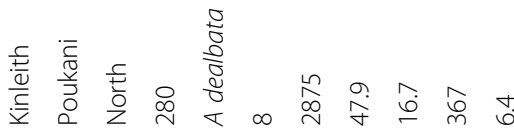

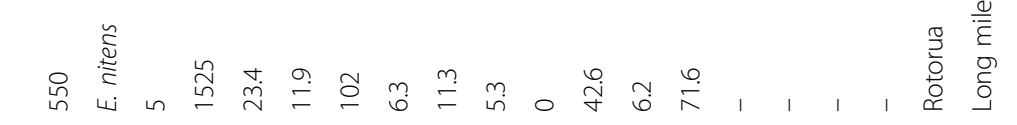

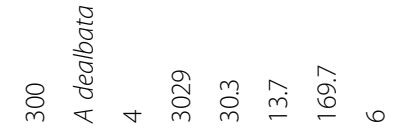

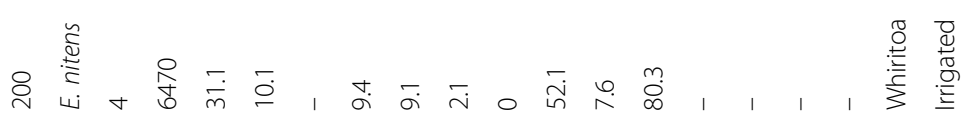
咅

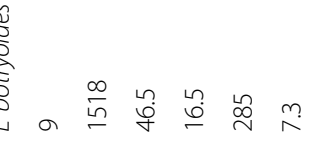

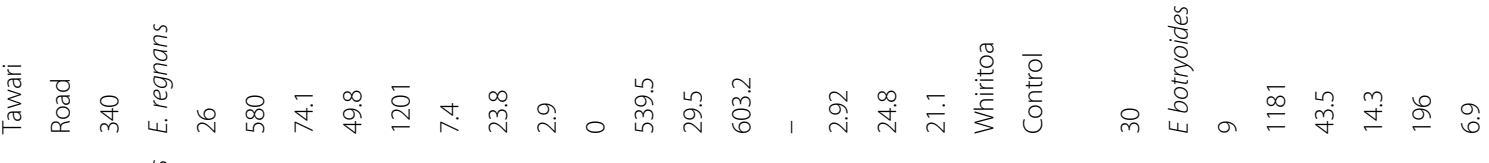

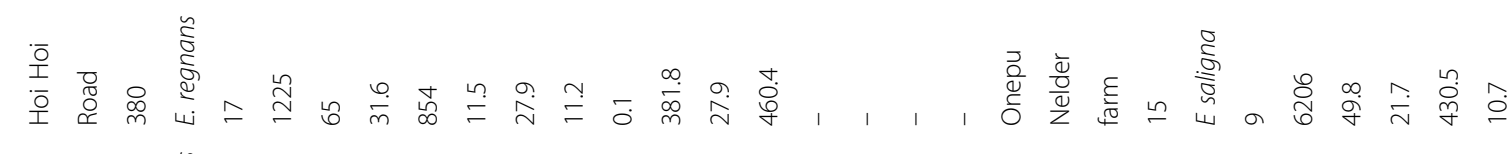

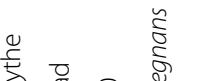

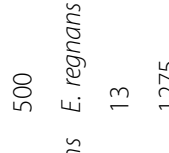

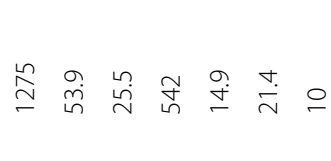

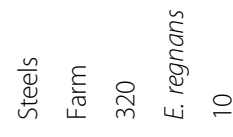

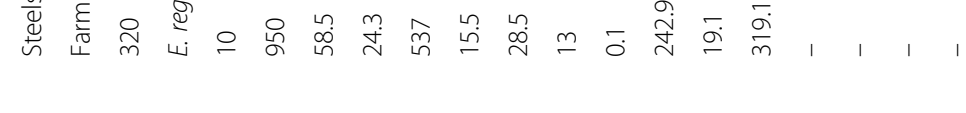

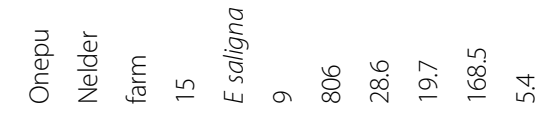

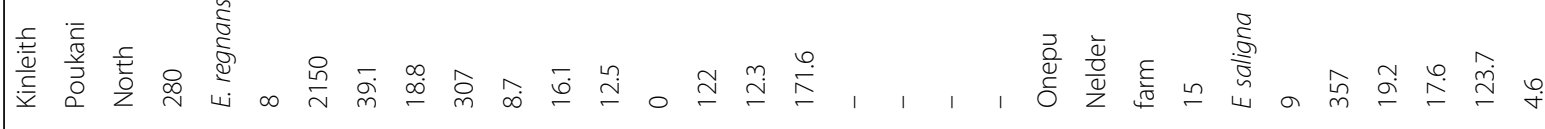

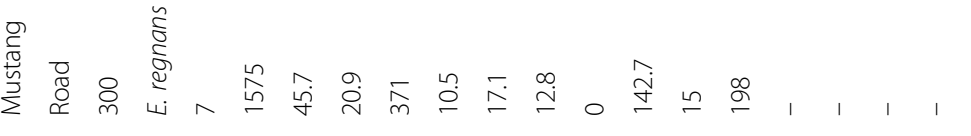




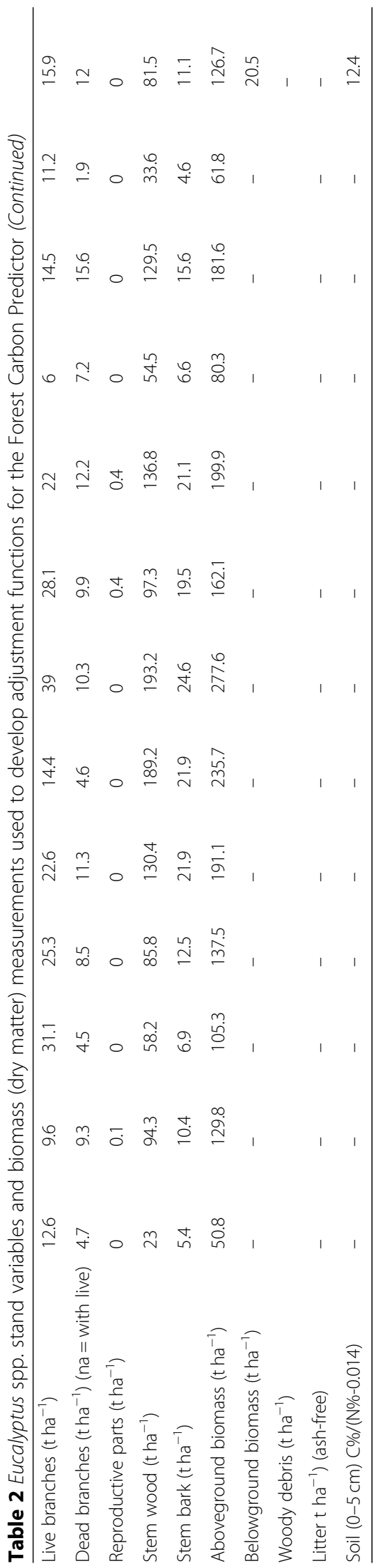




\section{Appendix 3}

Table 3 Breast-height (1.4 m) outerwood basic density (BHBD) for commercial species averaged across all New Zealand studies in Scion's wood density database

\begin{tabular}{|c|c|c|c|c|c|c|c|c|}
\hline \multirow[b]{2}{*}{ Species } & \multirow[b]{2}{*}{ Mean BHBD } & \multirow[b]{2}{*}{ No. of regions } & \multirow[b]{2}{*}{ No. of studies } & \multirow[b]{2}{*}{ Total no. trees } & \multirow[b]{2}{*}{ Region $p$ value } & \multicolumn{3}{|c|}{ Age regression } \\
\hline & & & & & & Intercept & Slope & $p$ value \\
\hline Acacia dealbata & 406 & 3 & 8 & 62 & 0.0189 & 385 & 4.7 & 0.2153 \\
\hline Cupressus lusitanica & 361 & 9 & 24 & 283 & 0.0261 & 339 & 1.3 & 0.0225 \\
\hline Eucalyptus botryoides & 512 & 3 & 8 & 51 & 0.5848 & 425 & 5 & 0.0017 \\
\hline Eucalyptus fastigata & 450 & 2 & 6 & 22 & 0.5433 & 389 & 2.4 & 0.0003 \\
\hline Eucalyptus nitens & 437 & 4 & 15 & 117 & 0.0414 & 400 & 4.7 & $<.0001$ \\
\hline Eucalyptus regnans & 406 & 6 & 28 & 159 & 0.0643 & 380 & 1.7 & $<.0001$ \\
\hline Eucalyptus saligna & 509 & 5 & 16 & 97 & 0.0552 & 446 & 3 & 0.0002 \\
\hline
\end{tabular}

Statistically significant $p$ values $(p \leq 0.05)$ for region and stand age are shown in italics

\section{Appendix 4}

Table 4 Cupressus lusitanica stand variables and biomass (dry matter) measurements used to develop adjustment functions for the Forest Carbon Predictor

\begin{tabular}{|c|c|c|}
\hline Locality & Rotorua & Manawahe \\
\hline Site name and year planted & Long Mile & Farm site \\
\hline Elevation (m) & 290 & 360 \\
\hline Age (years) & 29 & 20 \\
\hline Stocking rate $\left(\right.$ Trees ha $\left.{ }^{-1}\right)$ & 935 & 580 \\
\hline Basal area $\left(\mathrm{m}^{2} \mathrm{ha}^{-1}\right)$ & 75.4 & 47.3 \\
\hline Mean Top Ht (m) & 28.9 & 21.6 \\
\hline $\operatorname{Vol}_{\text {ib }}\left(\mathrm{m}^{3} h \mathrm{a}^{-1}\right)$ & 885 & 404 \\
\hline Foliage \& Live branches $\left(\mathrm{t} \mathrm{ha}^{-1}\right.$ ) & 53.6 & 60.7 \\
\hline Dead branches $\left(\mathrm{t} \mathrm{ha}^{-1}\right)$ (na = with live) & 63.6 & 33.0 \\
\hline Reproductive parts $\left(\mathrm{t} \mathrm{ha}^{-1}\right)$ & 0 & 0 \\
\hline Stem wood $\left(\right.$ tha $\left.^{-1}\right)$ & 311.7 & 142.9 \\
\hline Stem bark $\left(\mathrm{t} \mathrm{ha}^{-1}\right)$ & 27.2 & 13.2 \\
\hline Aboveground biomass $\left(\mathrm{t} \mathrm{ha}^{-1}\right)$ & 456.1 & 249.8 \\
\hline Belowground biomass $\left(\mathrm{t} \mathrm{ha}^{-1}\right.$ ) & - & - \\
\hline Woody debris (t ha ${ }^{-1}$ ) & 0.0 & 2.68 \\
\hline Litter t ha ${ }^{-1}$ ) (ash-free) & 59.1 & 11.3 \\
\hline Soil $(0-5 \mathrm{~cm}) \mathrm{C} \% /(\mathrm{N} \%-0.014)$ & 18.7 & 15.1 \\
\hline
\end{tabular}




\section{Abbreviations}

AGL: Aboveground live; BGL: Belowground live; C: Carbon; C/(N0.014): Adjusted Carbon:Nitrogen ratio; CWD: Coarse woody debris (called Dead wood in the F(P); DBH: Diameter at breast height; DM: Dry matter; FCP: Forest Carbon Predictor; IPCC: Intergovernmental Panel on Climate Change; LFH: Litter, fermenting, and humus (collectively called Litter in the FCP); MAT: Mean annual temperature; N: Nitrogen; NIWA: National Institute of Water and Atmosphere Research; PMEN: Douglas-fir; PRAD: Radiata pine

\section{Acknowledgements}

Funding was received from the Ministry for the Environment under Statement of Work 21078 to publish biomass studies in Douglas-fir, eucalyptus, and cypress stands and undertake analysis to improve the Forest Carbon Predictor model accuracy. We greatly appreciate the assistance provided by forest managers who granted access to biomass sites and made available stand records. Technical support was provided by Tony W. Evanson, John R. Lee, Kane Fleet, Mark Miller, and Pat Hodgkiss with field work. Russell McKinley and Christine Dodunski undertook the wood density analysis. Alan Nordmeyer provided us with biomass and soil data used in this paper, and we appreciate the time he freely gave providing answers to questions we had regarding the biomass study sites and measurement procedures.

\section{Funding}

Funding to facilitate data analysis and publication of the model was provided by the Ministry for the Environment under Head Agreement Reference 20059, Statement of Work 21078.

\section{Availability of data and materials}

Please contact corresponding author for data requests.

\section{Authors' contributions}

PNB developed the concept for this manuscript and was the primary author. MOK implemented the adjustment functions in the FCP and contributed to writing the paper. GRO and SHP undertook the biomass sampling, sample processing, and contributed to writing the paper. All authors read and approved the final version of the manuscript

\section{Ethics approval and consent to participate}

Not applicable

\section{Consent for publication}

Not applicable

\section{Competing interests}

The authors declare that they have no competing interests.

\section{Publisher's Note}

Springer Nature remains neutral with regard to jurisdictional claims in published maps and institutional affiliations.

\section{Received: 20 February 2018 Accepted: 3 December 2018}

Published online: 28 December 2018

\section{References}

Beets, P. N., \& Garrett, L. G. (2018). Carbon fraction of Pinus radiata biomass components within New Zealand. New Zealand Journal of Forestry Science, 48:14

Beets, P. N., Kimberley, M. O., \& McKinley, R. B. (2007a). Predicting wood density of Pinus radiata annual growth increments. New Zealand Journal of Forestry Science, 37, 241-266.

Beets, P. N., Kimberley, M. O., Oliver, G. R., \& Pearce, S. H. (2018). Predicting wood density of growth increments of Douglas-fir stands in New Zealand. New Zealand Journal of Forestry Science, 48, 8.

Beets, P. N., Kimberley, M. O., Paul, T. S. H., \& Garrett, L. G. (2011). Planted Forest Carbon Monitoring System - forest carbon model validation study for Pinus radiata. New Zealand Journal of Forestry Science, 41, 177-189.

Beets, P. N., Pearce, S. H., Oliver, G. R., \& Clinton, P. W. (2007b). Root/shoot ratios for deriving below-ground biomass of Pinus radiata stands. New Zealand Journal of Forestry Science, 37, 267-288.

Beets, P. N., Robertson, K. A., Ford-Robertson, J. B., Gordon, J., \& Maclaren, J. P. (1999). Description and validation of C-Change: a model for simulating carbon content in managed Pinus radiata stands. New Zealand Journal of Forestry Science, 29, 409-427.

Cown, D. J., McConchie, D. L., \& Young, G. D. (1991). Radiata pine wood properties survey. [FRI Bulletin No. 50 (Revised edition)]. Wellington: Ministry of Forestry.

Frederick, D. J., Madgwick, H. A. I., Jurgensen, M. F., \& Oliver, G. R. (1985a). Dry matter, energy and nutrient contents of 8-year old stands of Eucalyptus regnans, Acacia dealbata and Pinus radiata in New Zealand. New Zealand Journal of Forestry Science, 15, 142-157.

Frederick, D. J., Madgwick, H. A. I., Jurgensen, M. F., \& Oliver, G. R. (1985b). Dry matter and nutrient content of 8-year-old Eucalyptus saligna growing at Taheke forest. New Zealand Journal of Forestry Science, 15, 251-254.

Frederick, D. J., Madgwick, H. A. I., Jurgensen, M. F., \& Oliver, G. R. (1985c). Dry matter content and nutrient distribution in an age series of Eucalyptus regnans plantations in New Zealand. New Zealand Journal of Forestry Science, 15, 158-179.

Frederick, D. J., Madgwick, H. A. I., Jurgensen, M. F., \& Oliver, G. R. (1986). Seasonal development of a young plantation of Eucalyptus nitens. New Zealand Journal of Forestry Science, 16, 78-86.

Garrett, L. G., Kimberley, M. O., Oliver, G. R., Pearce, S. H., \& Beets, P. N. (2012). Decomposition of coarse woody roots and branches in managed Pinus radiata plantations in New Zealand - a time series approach. Forest Ecology and Management, 269, 116-123.

Garrett, L. G., Kimberley, M. O., Oliver, G. R., Pearce, S. H., \& Paul, T. S. H. (2010). Decomposition of woody debris in managed Pinus radiata plantations in New Zealand. Forest Ecology and Management, 260, 1389-1398.

Haslett, A. N. (1986). Properties and utilisation of exotic specialty timbers grown in New Zealand. Part 111: The Cypresses. [FRI Bulletin No. 119]. Rotorua: Forest Research Institute/New Zealand Forest Service.

IPCC. (2003). Good practice guidance for land use, land-use change, and forestry. Institute for Global Environmental Studies (IGES) for the IPCC. Geneva: IPCC.

Kimberley, M. O., West, G. G., Dean, M. G., \& Knowles, R. L. (2005). The 300 Index a volume productivity index for radiata pine. New Zealand Journal of Forestry, 50, 13-18.

Knowles, R. L. (2005). Development of a productivity index for Douglas-fir. New Zealand Journal of Forestry, 50, 19-22.

Madgwick, H. A. I. (1981). Estimating the above-ground weight of forest plots using the basal area ratio method. New Zealand Journal of Forestry Science, 11(3), 278-286

Madgwick, H. A. I., Beets, P., \& Gallagher, S. (1981). Dry matter accumulation, nutrient and energy content of the above-ground portion of 4-year old stands of Eucalyptus nitens and E. fastigata. New Zealand Journal of Forestry Science, 11, 53-59.

Ministry for Primary Industries. (2016). National Exotic Forest Description as at 1 April 2016. Wellington: Ministry for Primary Industries.

Nordmeyer, A. H., \& Ledgard, N. J. (1993). Above-ground biomass, productivity, and nutrients in 15-year-old stands of Ponderosa pine, Corsican pine, Douglas-fir, and European larch in the Craigieburn Range, New Zealand. Studia Forestalia Suecica, 191, 75-85.

Ranger, J., \& Gelhaye, D. (2001). Belowground biomass and nutrient content in a 47-year-old Douglas-fir plantation. Annals of Forest Science, 58, 423-430.

Snowden, P., Eamus, D., Gibbons, P., Khanna, P., Keith, H., Raison, J., \& Kirschbaum, M. (2000). Synthesis of allometrics, review of root biomass and design of future woody biomass sampling strategies. [National Carbon Accounting System Technical Report No. 17]. Canberra: Australian Greenhouse Office.

Van der Werff, H. S. (1988). Cypress Canker in New Zealand plantations. New Zealand Journal of Forestry Science, 18, 101-108. 